\title{
Moderating Impact of Educational Level on Religiosity asan Antecedent of Ethical Behavior
}

\author{
SadiaArshad \\ Department of Business Administration, Foundation University, Rawalpindi,Pakistan
}

\begin{abstract}
This study aims to explore the influence of religiosity on ethical behavior of public servants of Pakistan at their work setting, taking education levels as moderator. Religiosity has long been considered as main determinant in shaping ethical values and educational level strengthens its relationship. The wellestablished scale of ethical behavior and religiosity was adapted. Sample sizeof 350 employees of public servants working in different ministries was obtained. There are two dimensions of religiosity - extrinsic religiosity and intrinsic religiosity. Results showed that extrinsic religiosity and intrinsic religiosity were a significant determinant of ethical behavior of public servants, whereas educational level moderates the relationship of ethical behavior and religiosity.
\end{abstract}

Key Words: Intrinsic Religiosity, Extrinsic Religiosity, Ethical behavior

\subsection{Background}

\section{Introduction}

Many studies have been conducted to discover the relationship of religiosity and ethical behaviors of people in their organizational life to answer questions like, What should be the standard for determining or measuring ethical behavior? How to distinguish between right and wrong? And what should be the behavior of public servants? There is no general or universal standard to measure ethical behavior but still there exists difference in the perception of ethics of different individuals and human in groups.

Religion often contributes a lot to ethical behavior in organizations. Johnson et al (2001), defined religiosity as "the degree to which an individual is devoted to the religion or faith one admits and follows its teachings." In this regard individual's behaviors imitate this devotion or commitment. Whereas, ethical behavior defined by Ruud (2001), "is the accepted system of beliefs that can control behavior." Researches were conducted find out the impact of religiosity on the ethical behavior. Like, Fort (2000) contented that instead of making religion apart from ethics it should be studied together. Religion makes a lot of contributions to ethical behavior (McMahon. 1986). There should be general ethics that can be basic foundation for getting harmony in human behavior and it can only be received from religion only. (Asad, 1986). People's way of life, knowledge, faith and attitudes are shaped by religious commitment. Thus, religion is one of the most significant forces in the lives of people stating what is religiously acceptable and likeable and what is not.

Hunt and Vitell (2000) contended that religiosity have an influence on an individual's sensitivity of ethics. He argues that religion, cultural environment and personal characteristics are the three ways that influence ethical behaviors. Among them religion is a dominant factor that shape up duty, moral obligation, and moral commitment of human being.

The aim of this research is to examine the influence of religiosity on the ethical behavior of public officials. It will provide evidence whether their intrinsic religious believes impact their ethical behavior or not. On the other hand educational level will be treated as moderator to check whether more educated servants are more ethical and vice-versa. And examine, educational level impact the religious understanding of the public employees or not.

\subsection{Significance of the study:}

Religiosity and ethical behavior has received a lot of attention of the researchers in the recent years both in practical and theoretical spheres. However, it has not been demonstrated that what impact educational level creates on the relationship of religiosity and ethical behavior. This research contributes to new field of study by exploring the moderating impact of educational level on the two variables. This study purposes educational level as a strong contingent factor which moderates the relationship of religiosity and ethical behavior. Furthermore, the previous researches were conducted mostly in western settings. This study will contribute to eastern work settings 


\subsection{The Relationship between Religiosity and Ethical Behavior \\ II. Literature Review}

There exists a positive relationship between intrinsic religiosity and ethical attitudes from the point of view of intrinsic religiosity and extrinsic religiosity dimensions (Aydemir et al., 2009). People who are intrinsically motivated, they have more positive ethical attitudes than extrinsically motivated people. (Donahue, 1985). According to Vitell et al (2005), Intrinsic religiosity is a determinant of ethical beliefs. It means that one have more sense of intrinsic religiosity, more likely he/she will have as "questionable" business activities as wrong (Vitell et al. 2005; Vitell and Muncy, 2005; Vitel et al. 2006; Vitell et al. 2007). According to Allport and Ross (1967), the positive relations between religiosity and ethical behavior can be explained by "extrinsically motivated person uses his religion whereas the intrinsically motivated lives his religion." The main motive of person with intrinsic religiosity orientation is in religion the reason behind this is that he internalized his religious belief or faith; therefore his religious beliefs direct his behavior in areas of life whether it is his social and business life he is led by this behavior throughout. (Allport, 1990). There is a positive relationship between Attending religious activities or Practicing religious beliefs and the ethical attitudes (Pahu, 2007). People consider themselves more ethically minded who practiced their religion (Kea, 2007). People who practice their religion are less expected to cheat and are more likely to be honest than those who do not practice their religion. (Bloodgood et al, 2008, Perrin, 2000). According to Some studies generally religiosity has a positive impact on ethical attitudes (Kennedy and Lawton, 1998; Singhapakdi et al., 2000; Siu et al., 2000; Conroy and Emerson, 2004). In the light of previous theoretical and empirical literature, following hypotheses are generated involving religiosity and to test the ethical attitudes of public servants:

H1: Intrinsic religiosity has positive effect on ethical behavior of public servants.

H2: Extrinsic religiosity has positiveeffect on ethical behavior of public servants.

\subsection{The Relationship between Religiosity, Ethical behavior and Educational level}

People who have strong religious faith or belief may already have a knowhow of the concepts that are being taught in the class (Bloodgood, 2008). Therefore, it can be contented that educational level or school or college learning helps a person to choose between right or wrong. It makes an individual or group to adopt an ethical or unethical behavior depending upon the understanding of the individual (Mudrack,2008). In shaping the ethical behavior of individual education plays a vital role. According to bloodgood (2008), ethics individual having higher level of education do not compromise on ethics they adopt during a situation. There exist a great difference between high educated respondents and less educated ones in the terms of professional ethics Giacalone et al. (1999). In other words they do not compromise on their ethics (Kraft \&Singhapakdi, 1991). Furthermore, He argues that some situation will attract less educated people to adopt unethical behavior.

Hegre( 2003) says that there are many factors that get influenced by education and ethics is one of them and it will strengthen the relationship. In the light of previous theoretical and empirical literature, following hypotheses is generated involving educational level and to test the ethical attitudes of public servants and to explore the role of educational level as a moderator

Some researches claim that more religious students are better in their studies or academic life (Glass \& Jacobs, 2005). Religiosity provides the students with better options than other actions (Lehrer, 2004). There are some religious factors that impact the education level positively on the other hand there are some which weaken the educational attainment. (Darnell \&Sherkat 1997;Sherkat\& Darnell 1999).

There are two factors that can undermine bad activity engagement. They are personal religiosity and Religious participation which can lessen those activities that can damage careers and decreases the rate of substance abuse. (Regnerus, 2000). The students having intrinsic religiosity are anticipated to dedicate time and force to a diversity of pro-social causes (Wilson \&Janoski 1995). Glaeser (2002) contended that educational level and religiosity are positively correlated with each other. It means person having high level of educational level will have better understanding of the beliefs (Lipset, 1990). Therefore educational level will be treated as moderator in this research. The impact of educational level will be evaluated with ethical behavior and religiosity.In the light of previous theoretical and empirical literature, following hypotheses are generated involving religiosity and to test the impact of educational level on the public servants:

H3: Educational level moderates the relationship of intrinsic religiosity and ethical behavior.

H4: Educational level moderates the relationship of extrinsic religiosity and ethical behavior. 


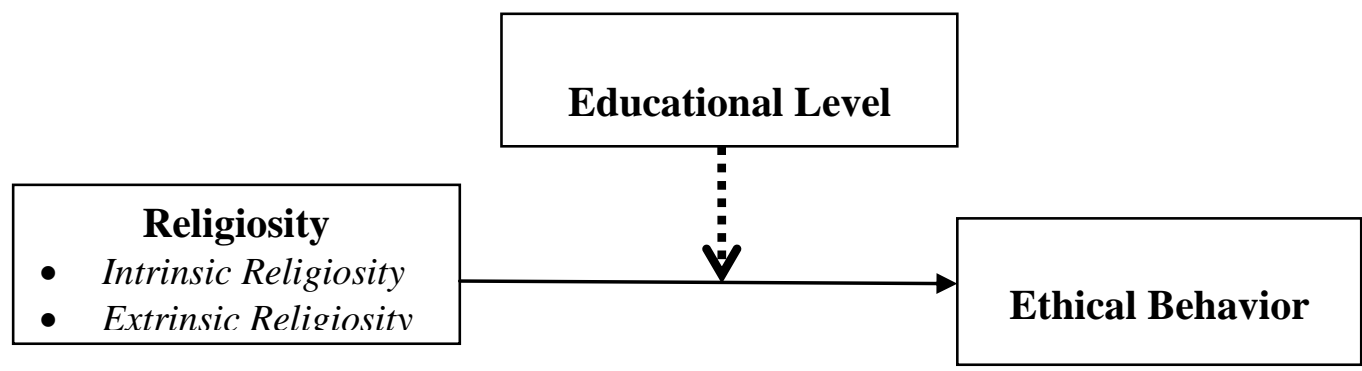

\section{Methodology}

This is a quantitative research. The study design of this research is causal in nature and the design is cross-sectional as data is collected once from the participants.

The participants of the research were the public servants who were the employees of different ministries. The organizations are Pakistan National Council of the Arts, Pakistan Agriculture Research Council, and Planning and development commission of Pakistan staff these organizations comes under the tandem of Ministry of Finance, Ministry of Heritage and Integration and Ministry of agriculture. The minimum age of participants is 20 years and minimum educational level was metric.

To collect the responses convenient sampling is used. It is drawn from population which is close to hand and easy to approach.

The sample size of the research is 350 . The questionnaire was filled by 300 employees of public organizations or in other words the response rate was $85 \%$ only. The questionnaires were filled by the public servants serving in the different Ministries of Pakistan.

The data was collected from the public servants of the ministries through survey method. The respondents were asked to rate each of the question on a 5-point likert scale ranging from strongly disagree (1) to strongly agree (5). Following instruments were used in the study:

\subsection{Religiosity}

To measure religiosity Religious Commitment Inventory scale of Worthington et al. (2003) is used. The extrinsic religiosity consists of 6 items and intrinsic religiosity comprise of 4 items.

\subsection{Ethical Behavior}

The ethical behavior is measured by using different scales developed by researchers. In this research the ethical behavior is measured by using Kaptein (2008) scale. It is 30 -item scale.

Pilot study was conducted to check the reliability of adopted questionnaire. Sample of 40 respondents were taken to carry the check the reliability.The Alpha Reliability value for the intrinsic religiosity, extrinsic religiosity and ethical behavior was measured as above 0.7 showing the strong internal consistency for the tool.

Table1 Reliability of three variables

\begin{tabular}{ccc}
\hline Variable & Cronbach Alpha & No of items \\
Extrinsic Religiosity & .86 & 6 \\
Intrinsic Religiosity & .80 & 4 \\
Ethical Behavior & .85 & 29
\end{tabular}

A value of $0.84,0.80$, and 0.85 confirms the reliability of the questionnaire used for the collection of the data.

\section{Analysis Of Data}

The results were computed by using Statistical Package for Social Sciences (SPSS). Testing of hypothesis was done through correlation and multiple regression of coefficient analysis.

Table 2: Regression analysis of extrinsic religiosity, intrinsic religiosity and ethical behavior. Coefficients $^{\mathrm{a}}$

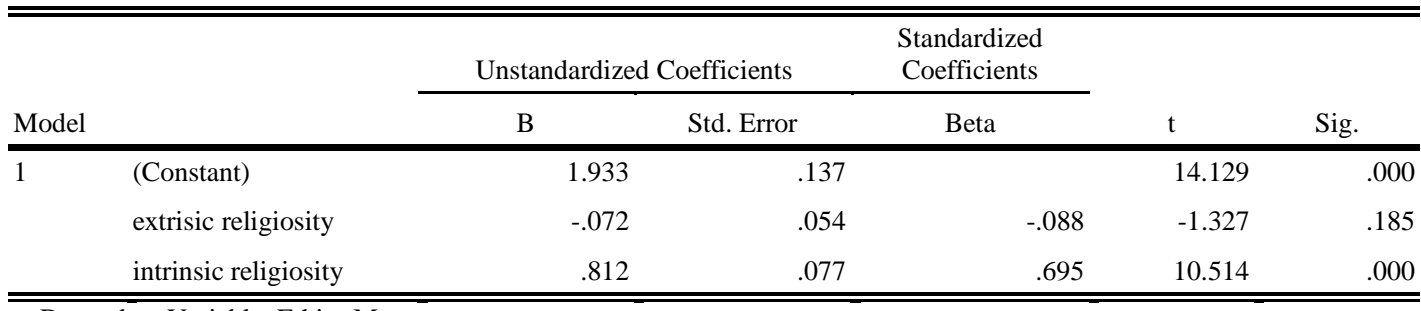

a. Dependent Variable: Ethics Mean 
Table 2 shows the relationships between three variables under study. The results of analysis disclosed that the intrinsic religiosity posses a very strong positive relationship with ethical behavior $(\beta=.70, \mathrm{p}<.00)$. Pvalue is less than $1 \%$, the coefficient is highly significant, and it can be asserted true with $99 \%$ level of confidence. Thus this hypothesis results suggests that intrinsic religiosity is positively related to ethical behavior of public servants. Therefore the results are accepted, accepting the hypothesis 1 . On the other hand, the results of analysis disclosed that the extrinsic religiosity posses a negative relationship with ethical behavior $(\mathrm{B}=-.09, \mathrm{p}>.05)$. P-value is greater than $5 \%$, the coefficient isinsignificant. Therefore the results are rejecting $\mathrm{H} 2$.

To verify for the moderation of educational level, method of stepwise hierarchical regression method was used. For moderation to take place it is necessary that independent variables must influence dependent variable. The regression table above revealed that extrinsic religiosity does not influence ethical behavior. This means that $\mathrm{H} 4$ of the research is rejected. In other words, educational level does not moderate the relationship between extrinsic religiosity and ethical behavior. Therefore the moderation test is carried on intrinsic religiosity and ethical behavior only. The tables below show the relationship of intrinsic religiosity and ethical behavior and showing moderating impact of educational level. The table depicts H3 and H4 of the research.

Table 3:Model summary of moderation Model Summary

\begin{tabular}{lcccc}
\hline \hline Model & $\mathrm{R}$ & $\mathrm{R}$ Square & Adjusted R Square & $\begin{array}{c}\text { Std. Error of the } \\
\text { Estimate }\end{array}$ \\
\hline 1 & $.631^{\mathrm{a}}$ & .398 & .396 & .77712581 \\
2 & $.661^{\mathrm{b}}$ & .437 & .433 & .75316985 \\
\hline \hline a. Predictors: (Constant), Zscore: intrinsic religiosity & \\
b. Predictors: (Constant), Zscore: intrinsic religiosity, $\bmod 1$ &
\end{tabular}

The table above shows model summary of moderation. The factor $\mathrm{R}^{2}$ shows that how much impact or effect does one variable has on the other variable. In the above table, model 1 revealed that $\mathrm{R}^{2}=.40$. This means that there is $40 \%$ impact of intrinsic religiosity on ethical behavior. Rest $60 \%$ depends on factors which have not been highlighted in this study that is for scholars and researchers to find out. Whereas, the increased value of R shows that educational level moderates the relationship between religiosity and ethical behavior.

Table 4: Coefficients table of moderation

\begin{tabular}{|c|c|c|c|c|c|c|}
\hline \multicolumn{7}{|c|}{ Coefficients $^{\mathrm{a}}$} \\
\hline \multicolumn{2}{|c|}{ Model } & \multicolumn{2}{|c|}{ Unstandardized Coefficients } & $\begin{array}{c}\begin{array}{c}\text { Standardized } \\
\text { Coefficients }\end{array} \\
\text { Beta }\end{array}$ & $\mathrm{t}$ & Sig. \\
\hline \multirow[t]{2}{*}{1} & (Constant) & 4.490 & .045 & & .000 & 1.000 \\
\hline & Zscore: intrinsic religiosity & .631 & .045 & .631 & 14.039 & .000 \\
\hline & Zscore: intrinsic religiosity & .602 & .044 & .602 & 13.678 & .000 \\
\hline & $\bmod 1$ & -.085 & .019 & -.198 & -4.501 & .000 \\
\hline
\end{tabular}

a. Dependent Variable: Zscore: Ethics Mean

Table 4 shows the moderation effect of educational level on intrinsic religiosity. After the moderator is entered in the step two through interaction term (RM2*educational level) which revealed that interaction term is highly significant at $\beta=.63, \mathrm{R}^{2}$ change of .43 . Basically $\mathrm{R}^{2}$ change value represents the increase in $\mathrm{R}^{2}$ from the inclusion of moderator in regression model. $\mathrm{R}$ square change shows that there moderation of educational level. The results show that $\mathrm{p}<.00$ which means $99.99 \%$ confidence level. Therefore the results support the presence of significant moderating effect. Thus we can say hypothesis 3 is accepted. That is, educational level moderates the relationship of intrinsic religiosity and ethical behavior.

\section{Conclusion}

Based on objectives of the research, following conclusion has been drawn:

- Educational level moderates the relationship of intrinsic religiosity and ethical behavior. 
- Findings of the study revealed that there exists association between religiosity and ethical behavior of the public servants.

- The finding showed that extrinsic religiosity and ethical behavior of the public servants are negatively correlated. Whereas, intrinsic religiosity and ethical behavior positive relation, as contended by the previous researches. It means that intrinsic religiosity appears to explain an individual's attitude toward unethical practices. The individuals having higher level of intrinsic religiosity, they consider questionable practices as wrongful acts. But in the Pakistanis context the relationship of extrinsic religiosity and ethical behavior is positive.

- Educational level plays the role of moderator. It strengthens the relationship of religiosity and ethical behavior of the public servant. It means individuals having more level of educational attainment had better understanding of their beliefs or faith, and they less practice less ethical practices

\subsection{Recommendations for future researches}

Following are the recommendations for future studies:

- The future researches could include other ethnic group into the sample for better results.

- It is also recommended to explore other factors influencing ethical behavior, e.g. competition, cultural background and love for money.

- The moderating effect can be examined by other factors like gender, age, psychological factors etc.

\section{References:}

[1]. Allport, G. W. (1990). The Individual and Religion. Newyork: Mac Millan. Delener, N. (1994). Religious contrasts in consumer decision behaviour patterns: Their dimensions and marketing implications. European Journal of Marketing, 28(5), 3653.

[2]. Allport, G. W. and Ross, J. M. (1967) "Personal Religious Orientation and Prejudice." Journal of Personality and Social Psychology, 5, 432-443.

[3]. Alesina, Alberto \&Perotti, 1996. 'Income Distribution, Political Instability, and Investment', European Economic Review 40 (June): 1203-1228.

[4]. Amabile, Teresa M. (1997) "Motivation Creativity in Organizations: On Doing What You Love And Loving What You Do", California Management Review, Vol. 40, No. 1, Fall, pp.39-58.

[5]. Amabile, T.M. (1996) Creativity in Context: Update to the Social Psychology of Creativity, Boulder, CO: West view Press

[6]. Aydemir, M.; Göksu, A.; Obralic, M. (2009) "The Impacts of Religiosity on the Ethical Attitudes of the Prospective Managers", 1. International Symposium on Sustainable Development - ISSD '09, June 9-10, 2009, Sarajevo, Bosnia and Herzegovina, Volume 1, pp.100-104.

[7]. Bernardin, Andrew (2006). Religion and Behavior, Skeptic, Volume 12, Number 3, pp.22-25.

[8]. Bloodgood, James M., Turnley, William H. and Mudrack, Peter (2008). The Influence of Ethics Instruction, Religiosity, and Intelligence on Cheating Behavior, Journal of Business Ethics, 82:557-571.

[9]. Boppart, T., Falkinger, J., Grossmann, V., Woitek, U. and Wu"thrich, G. (2008), "Qualifying religion: the role of plural identities for educational production", working paper series, Institute for Empirical Research in Economics University of Zurich, Zurich.

[10]. Conroy, S. J. and Emerson, T. L. N. (2004). Business Ethics and Religion: Religiosity as a Predictor of Ethical Awareness among Students. Journal of Business Ethics, 50: 383-396.

[11]. Clark, J. W. and L. E. Dawson: 1996, 'Personal Religiousness and Ethical Judgements: An Empirical Analysis', Journal of Business Ethics 15, 359-372. Conroy, S. J. and T. L. N. Emerson: 2004, 'Business

[12]. Darnell, Alfred and Darren E. Sherkat. 1997. "The Impact of Protestant Fundamentalism on Educational Attainment." American Sociological Review 62: 306-316.

[13]. Donahue, M. J. (1985) "Intrinsic and Extrinsic Religiousness: Review and Meta Analysis", Journal of Personality and Social Psychology, 48 (2): 400-419. Development - ISSD '09, June 9-10, 2009, Sarajevo, Bosnia and Herzegovina, Volume 1, pp.100104.

[14]. Ferrell, O. C. and L. G. Gresham: 2002, 'A Contingency Framework for Understanding Ethical Decision Making in Marketing', Journal of Marketing 49(Summer), 87-96

[15]. Fort, T. L. (2000). Religion and Business Ethics: The Lessons from Political Morality. Journal of Business Ethics, 16, 3,263-273.

[16]. Ford, R. C. and W. D. Richardson: 1994, 'Ethical Decision Making: A Review of the Empirical Literature', Journal of Business Ethics 13(3), 205-221.

[17]. Guiso, L., Sapienza, P. and Zingales, L. (2003), "People's opium? Religion and economic attitudes", Journal of Monetary Economics, Vol. 50 No. 1, pp. 225-82.

[18]. Glass, Jennifer and Jerry Jacobs. 2005. "Childhood Religious Conservatism and Adult Attainment among Black and White Women." Social Forces 84: 555-57

[19]. Hibbs, Douglas, 1973. Mass Political Violence: A Cross-National Causal Analysis. New York: Wiley.

[20]. Hunt, S. D. and Vitell, S. J. (2000), The General Theory of Marketing Ethics: A Retrospective and Revision, in N. C. Smith and A. John (eds.). Ethics in Marketing, Quelch (Irwin Inc., Homewood, IL), 775-784.

[21]. Huntington, Samuel P, 1968. Political Order in Changing Societies. Yale University Press.

[22]. Hunt, S. D. and S. J. Vitell: 1986, 'A General Theory of Marketing Ethics', Journal of MacroMarketing 8, 5-16.

[23]. Ibrahim, N. A.; Howard, D. P. and Angelidis, J. P. (2008). The Relationship between Religiousness and Corporate Social Responsibility Orientation: Are there Differences between Business Managers and Students? Journal of Business Ethics, 78: 165174.

[24]. Inglehart, R. and Norris, P. (2004), Sacred and Secular: Religion and Politics Worldwide, Cambridge University Press, Cambridge.

[25]. Jeynes, W. H. (2007). Religion, Intact Families, and the Achievement Gap. IJRR, 3(2006), 3.

[26]. Johnstone, R.L. (2001). Religion and society in interaction: The sociology of religion. Englewood Cliffs, NJ: Prentice-Hall. 
[27]. Kaptein, M. (2008). Developing a Measure of Unethical Behavior in the Workplace: A Stakeholder Perspective. Journal of Management, 34(5), 978-1008.

[28]. Kennedy, E. J. and Lawton, L. (1998). Religiousness and Business Ethics. Journal of Business Ethics, 17: $163-175$.

[29]. Koenig, H. G., McCullough, M. E., \& Larson, D. B., (2001). Handbook of religion and health. New York: Oxford University Press.

[30]. Kohlberg, L.: 1981, The Philosophy of Moral Development: Moral Stages and the Idea of Justice (Harper \& Row, San Francisco)

[31]. Lipset, Seymour M., 1990. 'Some Social Requisites of Democracy: Economic Development and Political Legitimacy', American Political Science Review 53(1): 69-106.Lutz, Wolfgang; Anne Goujon, Samir K.C. \& Warren Sanderson, 2007. Reconstruction of Population by Age, Sex and Level of Educational Attainment for 120 Countries 1970-2000. Laxenburg, Austria: IIASA.

[32]. Madigan, Tim (2005), The Basis of Morality, Philosophy Now, June/July, pp.36-39.

[33]. Phau, I. and Kea, G. (2007). Attitudes of University Students toward Business Ethics: A Cross-National Investigation of Australia, Singapore and Hong Kong. Journal of Business Ethics, 72: 61-75.

[34]. Regnerus, Mark D. 2000. "Shaping Schooling Success: Religious Socialization and Educational Outcomes in Metropolitan Public Schools." Journal for the Scientific Study of Religion 39: 363-370.

[35]. Saat, Maisarah Mohamed, Porter, Stacey, and Weedbine, Gordon (2009) "Does Religiosity Influence Ethical Sensitivity? An Investigation on Malaysian Future Accountants," Malaysian Accounting Review, Vol. 8, No. 2, 17-41.

[36]. Singhapakdi, A.; Marta, J. K.; Rallapalli, K. C. and Rao, C. P. (2000). Toward and Understanding of Religiousness and Marketing Ethics: An Empirical Study. Journal of Business Ethics, 27: 305-319.

[37]. Siu, N. Y. M; Dickinson, J. R. and Lee, B. Y. Y. (2000). Ethical Evaluations of Business Activities and Personal Religiousness. Teaching Business Ethics, 4: 239-256.

[38]. Vitell, S.J., \&Paolillo, G.P. (2003). Consumer ethics: The role of religiosity. Journal of Business Ethics, 46(August II), 151-162.

[39]. Vitell, S. J.; Paolillo, J. G. P. and Singh, J. J. (2006) "The Role of Money and Religiosity in Determining Consumers' Ethical Beliefs." Journal of Business Ethics, 64: 117-124.

[40]. Vitell, S. J.; Singh, J. J. and Paolillo, J. (2007) "Consumers' Ethical Beliefs: The Roles of Money, Religiosity and Attitude toward Business." Journal of Business Ethics, 73: 369-379.

[41]. Worthington, E.L., Jr., Wade, N.G., Hight, T.L., McCullough, M.E., Berry, J.T., Ripley, J.S., Berry, J.W., Schmitt, M.M., \&Bursley, K.H. (2003). The religious commitment inventory-10: development, refinement and validation of a brief scale for research and counselling. Journal of Counselling Psychology, 50(1), 84-96

Dear participant,

APPENDIX A

I am conducting a research survey on relationship of religiosity and ethical behavior with educational level as a moderating variable. In this regard we will be thankful for your cooperation and participation in this survey. All the information collected would be kept confidential and would be used only for research and data analyses purposes.

\section{1=Strongly Disagree; 2=Disagree; 3=Neutral; 4=Agree; 5=Strongly Agree}

\section{Please select the appropriate number against each statement, according to the scale given below}

\begin{tabular}{|c|c|c|c|c|c|}
\hline 1. I often read books and magazines about my faith. & 1 & 2 & 3 & 4 & 5 \\
\hline 2. I make financial contributions to my religious organization. & 1 & 2 & 3 & 4 & 5 \\
\hline 3. I spend time trying to grow in understanding of my faith. & 1 & 2 & 3 & 4 & 5 \\
\hline $\begin{array}{l}\text { 4. Religion is especially important to me because it answers many questions } \\
\text { about the meaning of life. }\end{array}$ & 1 & 2 & 3 & 4 & 5 \\
\hline 5. My religious beliefs lie behind my whole approach to life. & 1 & 2 & 3 & 4 & 5 \\
\hline 6. I enjoy spending time with others of my religious affiliation. & 1 & 2 & 3 & 4 & 5 \\
\hline 7. Religious beliefs influence all my dealings in life. & 1 & 2 & 3 & 4 & 5 \\
\hline $\begin{array}{l}\text { 8. It is important to me to spend periods of time in private religious thought and } \\
\text { reflection. }\end{array}$ & 1 & 2 & 3 & 4 & 5 \\
\hline 9. I enjoy working in the activities of my religious organization. & 1 & 2 & 3 & 4 & 5 \\
\hline $\begin{array}{l}\text { 10. I keep well informed about my local religious group and have some } \\
\text { influence in its decisions. }\end{array}$ & 1 & 2 & 3 & 4 & 5 \\
\hline
\end{tabular}

Please select an option by keeping in mind the behavior you and your supervisor show in different situations. 11. If you were to get hurt at work, you might be blamed rather than supported. 12. Even if an accident was not your fault, your superiors may still blame you. 13. You have been blamed for a superior's mistake.

14. You would be blamed for not following rules you do not have enough time to follow.

15. You would be blamed for not following rules you did not have the equipment to follow.

\begin{tabular}{|l|l|l|l|l|l|}
\hline 16. Your superiors do not always practice what they advocate. & $\mathbf{1}$ & $\mathbf{2}$ & $\mathbf{3}$ & $\mathbf{4}$ & $\mathbf{5}$ \\
\hline 17. There is a difference between the rules you are given in training and the & $\mathbf{1}$ & $\mathbf{2}$ & $\mathbf{3}$ & $\mathbf{4}$ & $\mathbf{5}$ \\
\hline
\end{tabular} 
rules you are expected to follow in the field.

18. Some policies and rules are very different from actual practices.

19. You are told to do things one way, but your superiors sometimes follow a different set of rules.

20. What your superiors say you are supposed to do and what you are expected to actually do are different.

21. Your superiors do not always follow the rules they set out for employees.

\begin{tabular}{|l|l|l|l|l|l|}
\hline & & & & & \\
\hline 1 & 2 & 3 & 4 & 5 \\
\hline 1 & 2 & 3 & 4 & 5 \\
\hline & 1 & 2 & 3 & 4 & 5 \\
\hline & 1 & 2 & 3 & 4 & 5 \\
\hline
\end{tabular}

22. You are in more danger of losing your job if you report too many problems.

23. You would be singled out by superiors if you complained about safety too much.

24. You may be punished against for reporting ethics violations.

\begin{tabular}{|l|l|l|l|l|l|}
\hline 1 & 2 & 3 & 4 & 5 \\
\hline 1 & 2 & 3 & 4 & 5 \\
1 & 2 & 3 & 4 & 5 \\
\hline
\end{tabular}

\begin{tabular}{|c|c|c|c|c|c|}
\hline 25. Some employees lie to cover up problems. & 1 & 2 & 3 & 4 & 5 \\
\hline 26. You have felt pressure to lie to cover up problems. & $\mathbf{1}$ & 2 & 3 & 4 & 5 \\
\hline $\begin{array}{l}\text { 27. You are given an "official" story for a stakeholder that is different than the } \\
\text { real story. }\end{array}$ & 1 & 2 & 3 & 4 & 5 \\
\hline 28. You have been asked to misrepresent things to the stakeholders. & 1 & 2 & 3 & 4 & 5 \\
\hline 29. Your coworkers would take bribes from stakeholders. & 1 & 2 & 3 & 4 & 5 \\
\hline
\end{tabular}

\begin{tabular}{|l|c|c|c|c|c|}
\hline 30. Some employees are treated more favorably than you. & $\mathbf{1}$ & $\mathbf{2}$ & $\mathbf{3}$ & $\mathbf{4}$ & $\mathbf{5}$ \\
\hline $\begin{array}{l}\text { 31. You would probably be promoted more quickly if you were of more friends } \\
\text { with your superiors. }\end{array}$ & $\mathbf{1}$ & $\mathbf{2}$ & $\mathbf{3}$ & $\mathbf{4}$ & $\mathbf{5}$ \\
\hline $\begin{array}{l}\text { 32. Employees in some departments are treated as more important than in other } \\
\text { departments. }\end{array}$ & $\mathbf{1}$ & $\mathbf{2}$ & $\mathbf{3}$ & $\mathbf{4}$ & $\mathbf{5}$ \\
\hline 33. Your superiors give special treatment to their favorite employees. & $\mathbf{1}$ & $\mathbf{2}$ & $\mathbf{3}$ & $\mathbf{4}$ & $\mathbf{5}$ \\
\hline $\begin{array}{l}\text { 34. Your concerns are not taken seriously because of the department you work } \\
\text { in. }\end{array}$ & $\mathbf{1}$ & $\mathbf{2}$ & $\mathbf{3}$ & $\mathbf{4}$ & $\mathbf{5}$ \\
\hline 35. You are asked to do things that are not safe. & $\mathbf{1}$ & $\mathbf{2}$ & $\mathbf{3}$ & $\mathbf{4}$ & $\mathbf{5}$ \\
\hline 36. You are asked to complete tasks in less amount of time. & $\mathbf{1}$ & $\mathbf{2}$ & $\mathbf{3}$ & $\mathbf{4}$ & $\mathbf{5}$ \\
\hline $\begin{array}{l}\text { 37. You do not always get the equipment needed to complete the task in better } \\
\text { way. }\end{array}$ & $\mathbf{1}$ & $\mathbf{2}$ & $\mathbf{3}$ & $\mathbf{4}$ & $\mathbf{5}$ \\
\hline $\begin{array}{l}\text { 38. You are expected to focus more on output of work rather than quality of } \\
\text { work. }\end{array}$ & $\mathbf{1}$ & $\mathbf{2}$ & $\mathbf{3}$ & $\mathbf{4}$ & $\mathbf{5}$ \\
\hline 39. Some of your superiors do not really care about your safety. & $\mathbf{1}$ & $\mathbf{2}$ & $\mathbf{3}$ & $\mathbf{4}$ & $\mathbf{5}$ \\
\hline
\end{tabular}

39. Some of your superiors do not really care about your safety.

Please encircle the appropriate response or fill in the blanks

\begin{tabular}{|l|l|l|l|l|}
\hline Gender & Male & Female & & \\
\hline Marital status & Single & Married & & \\
\hline Education & Intermediate & Graduation & Masters & Above \\
\hline Age & & & \\
\hline Name of the organization & & & \\
\hline Department & & & \\
\hline Area of specialization & & & \\
\hline Work experience & \multicolumn{4}{|l|}{} \\
\hline Designation & \multicolumn{4}{|l|}{} \\
\hline
\end{tabular}

